\title{
Kemampuan Mengidentifikasi Nilai-Nilai Kehidupan Dalam Cerpen Melalui Penerapan Model Pembelajaran Project Based Learning (PJBL) Di Kelas XI SMA Negeri 1 Labuapi
}

\author{
Ayu Nurmalayani \\ SMAN 1 Labuapi
}

\begin{abstract}
This study generally describes the ability of class XI students of SMA Negeri 1 Labuapi in identifying life values. This picture is taken from the results of the best practices of learning activities using project based learning methods. This research concludes several things. First, the activeness of students in learning is very high because most learning activities are responded to by all or most students. Second, almost all students have very good and good attitude or character. There were not even students who had bad behavior and only a few of them behaved well enough. For honesty, 87\% of students (20 people) are very good and 13\% (3 people) are good. For discipline 57\% (13 people) are very good, 26\% (6 people) are good, and 17\% (4 people) are good enough. For responsibility attitude $83 \%$ (19 people) are very good, $8.5 \%$ (2 people) are good, and $8.5 \%$ (2 people) are good enough. Meanwhile, for socialist attitudes 52\% (12 people) are very good, 39\% (9 people) are good, and 8.5\% (2 people) are good enough. Third, learning short stories by using Project Based Learning (PjBL) learning models assisted by local or contextual teaching materials, can improve students' abilities in identifying life values in short stories, which is up to 83\%. In this case, 19 out of 23 students completed / reached the KKM. Meanwhile, some things that can be recommended as a follow-up to the results of this activity are (1) teachers are advised to use the Project Based Learning (PjBL) learning model because it can increase student activity; and (2) teachers are advised to use material that is contextual or close to students' daily lives because it will be more quickly understood.
\end{abstract}

Keywords: ability, identify, life values, and PjBL

\begin{abstract}
Abstrak. Kajian ini secara umum menggambarkan kemampuan siswa kelas XI SMA Negeri 1 Labuapi dalam mengidentifikasi nilai-nilai kehidupan. Gambaran ini diambil dari hasil kegiatan best prctices pembelajaran menggunakan metode project based learning. Penelitian ini menyimpulkan beberapa hal. Pertama, keaktifan siswa dalam pembelajaran sangat tinggi karena sebagian besar kegiatan pembelajaran direspon oleh semua atau sebagian besar siswa. Kedua, hampir semua siswa memiliki sikap atau karakter yang sangat baik dan baik. Bahkan tidak dijumpai siswa yang memiliki perilaku tidak baik dan hanya beberapa saja yang berperilaku cukup baik. Untuk sikap jujur, 87\% siswa (20 orang) sangat baik dan 13\% (3 orang) baik. Untuk kedisiplinan 57\% (13 orang) sangat baik, 26\% (6 orang) baik, dan 17\% (4 orang) cukup baik. Untuk sikap tanggung jawab 83\% (19 orang) sangat baik, $8.5 \%$ (2 orang) baik, dan $8.5 \%$ (2 orang) cukup baik. Sementara itu, untuk sikap sosialis $52 \%$ (12 orang) sangat baik, 39\% (9 orang) baik, dan $8.5 \%$ (2 orang) cukup baik. Ketiga, pembelajaran cerpen dengan menggunakan model pembelajaran Project Based Learning (PjBL) berbantuan materi ajar local atau kontekstual, dapat meningkatkan kemampuan siswa dalam mengidentifikasi nilai-nilai kehidupan dalam cerpen, yakni sampai mencapai 83\%. Dalam hal ini, 19 dari 23 siswa tuntas/mencapai KKM. Sementara itu, beberapa hal yang dapat direkomendasikan sebagai lanjutan hasil kegiatan ini adalah (1) para guru disarankan menggunakan model pembelajaran Project Based Learning (PjBL) karena dapat meningkatkan keaktifan siswa; dan (2) para guru disarankan menggunakan materi yang kontekstual atau dekat dengan kehidupan keseharian siswa karena akan lebih cepat dipahami.
\end{abstract}

Kata kunci: Kemampuan, Mengidentifikasi, Nilai-Nilai Kehidupan, Dan PJBL

\section{PENDAHULUAN}

Mengingat pentingnya komunikasi dalam kehidupan manusia, pada setiap jenjang pendidikan, pembelajaran bahasa Indonesia selalu diarahkan untuk meningkatkan kemampuan berkomunikasi peserta didik. Dari empat jenis keterampilan berbahasa Indonesia yang ada, keterampilan berbahasa yang paling tampak terkait dengan kemampuan berkomunikasi adalah keterampilan berbicara dan menulis. Namun demikian, dalam kurikulum dan pembelajaran, tetap saja keempat keterampilan berbahasa itu harus dikembangkan secara seimbang.

Salah satu kompetensi yang harus dikuasai siswa kelas XI, yang sampai saat ini masih belum maksimal pencapaiannya di SMA Negeri 1 Labuapi adalah mengidentifikasi nilai-nilai kehidupan yang 
terkandung dalam kumpulan cerita pendek yang dibaca dan mendemonstrasikan salah satu nilai kehidupan yang dipelajari dalam cerita pendek (Depdikbud, 2018). Hal ini ditandai dengan masih rendahnya pencapaian siswa dilihat dari hasil belajar sebelumnya. Dari 23 siswa, hanya 10 orang siswa yang tuntas mencapai KKM, sisanya sebanyak 13 siswa memperoleh nilai di bawah KKM.

Jika dianalisis dengan cermat, beberapa hal yang menjadi penyebab renahnya pencapaian siswa pada kompetensi ini adalah (1) model pembelajaran yang diterapkan masih belum mampu mengaktifkan siswa dalam belajar, yakni masih didominasi guru dan hanya mengikuti tahapan pembelajaran dalam buku paket; (2) materi ajar yang digunakan terpaku pada materi yang ada di buku paket, yang ternyata jauh dari kehidupan keseharian siswa (misalnya cerpen-cerpen yang ada dibuku sangat jauh dari keseharian siswa); dan (3) pembelajaran cerpen atau sastra secara umum masih kurang mendapat perhatian serius dalam pembelajaran sehingga dibelajarkan sekenanya saja, bahkan terkadang dilewati. Intinya adalah bahwa penggunaan media dan strategi variatif belum dimaksimalkan dalam pembelajaran (Musaddat, dkk., 2016). Hal ini tidak lepas dari pentingnya strategi dan media pembelajaran. Strategi dan media tidak hanya sebagai alat bantu, tetapi juga merupakan bagian integral dalam pembelajaran yang berpotensi meningkatkan kompetensi siswa (Soeharto, dkk. 2003: 98). Untuk mencapai prestasi belajar, akan lebih maksimal apabila ditunjang oleh penataan faktor-faktor eksternal pembelajaran, seperti penggunaan media pembelajaran yang menarik, penggunaan strategi pembelajaran yang yang variatif, dan lain sebagainya (Soeharto, dkk 2003: 100).

Untuk mengatasi masalah yang terjadi di kelas XI SMA Negeri 1 Labuapi, dicoba kembangkan pembelajaran cerpen (mengidentifikasi nilai-nilai pada cerpen) dengan menggunakan model pembelajaran Project Based Learning (PjBL) berbantuan materi ajar local/kontekstual. Dalam hal ini, materi cerpen yang digunakan adalah materi cerpen yang dibuat sendiri oleh guru/penulis yang berisi unsur sosial-budaya di sekitar siswa. Hal ini dilakukan untuk mempercepat pemahaman siswa terhadap suatu kompetensi (Nurhadi, 2012).

Adapun jenis kegiatan yang dilakukan dalam rangka mengatasi permasalahan rendahnya kemampuan siswa kelas XI SMAN 1 Labuapi dalam pembelajaran cerpen adalah dengan melakukan maksimalisasi potensi pembelajaran. Dalam hal ini dilakukan beberapa tindakan, yiatu: (a) Pembelajaran dirancang dengan model Pembelajaran Project Based Learning (PjBL); (b) Materi yang digunakan dalam pembelajaran adalah materi ajar local/kontekstual, yakni materi cerpen yang digunakan adalah materi cerpen yang dibuat sendiri oleh guru/penulis yang berisi sosial-budaya sekitar siswa; dan (c) Semua tahapan pembelajaran diobservasi dan dilaporkan.

Pembelajaran Berbasis Proyek (Project Based Learning/PjBL) adalah strategi pembelajaran yang menggunakan proyek/kegiatan sebagai media._PjBL merupakan metode pembelajaran yang berfokus pada peserta didik dalam kegiatan pemecahan masalah dan tugas-tugas bermakna lainya (Kosasih, 2014:37). Pelaksanaan $P j B L$ dapat memberi peluang pada peserta didik untuk bekerja mengkonstruk tugas yang diberikan guru sehingga puncaknya dapat menghasilkan produk karya peserta didik. PjBL merupakan investigasi mendalam tentang sebuah topik dunia nyata yang berharga bagi atensi dan usaha peserta didik.

Senada dengan pandangan Kosasih, Daryanto (2014:23) juga menjelaskan bahwa PjBL merupakan metode belajar yang menggunakan masalah sebagai langkah awal dalam mengumpulkan dan mengintegrasikan pengetahuan baru berdasarkan pengalamannya dalam beraktivitas secara nyata. Dalam konteks ini, $P j B L$ dapat dipandang sebagai model pembelajaran yang melibatkan siswa secara aktif dalam merancang tujuan pembelajaran untuk menghasilkan produk atau proyek yang nyata (Sutirman, 2013:43). Lebih lanjut dijelaskan, keterlibatan siswa dalam proses pembelajaran dapat terjadi karena adanya produk atau 
proyek nyata yang harus dihasilkan sehingga siswa perlu merancang tujuan pembelajaran sesuai dengan minat dan pengetahuan mereka, baik secara individu maupun berkelompok. Abidin (2014:167) juga menjelaskan bahawa model PjBL sebagai suatu model pembelajaran, secara langsung melibatkan siswa dalam proses pembelajaran melalui kegiatan penelitian untuk mengerjakan dan menyelesaikan projek pembelajaran tertentu.

Oleh karena peserta didik memiliki gaya belajar yang berbeda, $P j B L$ memberikan kesempatan kepada mereka untuk menggali konten (materi) dengan menggunakan berbagai cara yang bermakna bagi dirinya dalam melakukan eksperimen secara kolaboratif (Sukardi, 2015). Menurut Keser \& Karahoca (2010), PjBL memiliki karakteristik sebagai berikut.

1) Peserta didik membuat keputusan tentang sebuah kerangka kerja.

2) Adanya permasalahan atau tantangan yang diajukan kepada peserta didik.

3) Peserta didik mendesain proses untuk menentukan solusi atas permasalahan atau tantangan yang diajukan.

4) Peserta didik secara kolaboratif bertanggungjawab untuk mengakses dan mengelola informasi untuk memecahkan permasalahan.

5) Proses evaluasi dijalankan secara berkesinambungan.

6) Peserta didik secara berkala melakukan refleksi atas aktivitas yang sudah dijalankan.

7) Produk akhir aktivitas belajar akan dievaluasi secara kualitatif.

8) Situasi pembelajaran sangat toleran terhadap kesalahan dan perbaikan.

Peran instruktur atau guru dalam $P j B L$ sebaiknya sebagai fasilitator, pelatih, penasehat, dan perantara. Hal ini dimaksudkan untuk mendapatkan hasil yang optimal sesuai dengan daya imajinasi, kreasi dan inovasi peserta didik. PjBL akan lebih menarik jika suasana ruang belajar tidak monoton. Hal ini bisa dilakukan dengan perubahan lay-out ruang kelas, seperti: traditional class (teori), discussion group (pembuatan konsep dan pembagian tugas kelompok), lab tables (saat mengerjakan tugas mandiri), circle (presentasi). Suasana belajar menyenangkan pun dapat dilakukan di taman atau halaman. Belajar tidak harus dilakukan di ruang kelas.

Setiap model atau metode pembelajaran memiliki langkah-langkah kegiatan. Demikian pula dengan metode PjBL. Menurut Daryanto (2014:27), langkahlangkah model pembelajaran berbasis proyek adalah (1) penentuan pertanyaan mendasar, (2) men-desain perencanaan proyek, (3) menyusun jadwal, (4) memonitor siswa dan kemajuan proyek, (5) menguji hasil, dan (6) mengevaluasi pengalaman. Dalam bentuk diagram, dapat disajikan sebagai berikut.

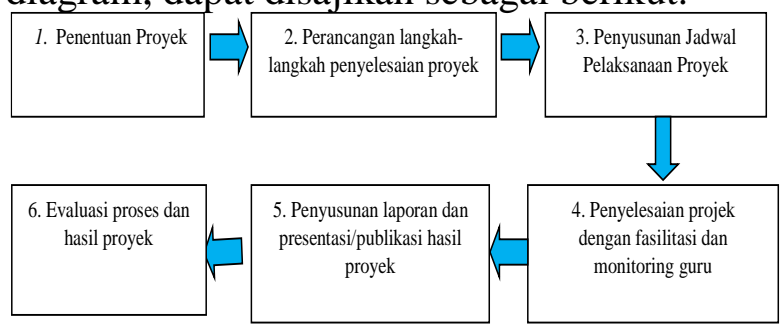

Gambar 1. Langkah-langkah PjBL (Sukardi, 2015)

Berdasarkan diagram di atas, dapat dijelaskan bahwa langkah-langkah penerapan $P j B L$ adalah sebagai berikut.

1) Penentuan Proyek. pada langkah ini, peserta didik menentukan tema/topik proyek berdasarkan tugas proyek yang diberikan oleh guru. Peserta didik diberi kesempatan untuk memilih/menentukan proyek yang akan dikerjakannya baik secara kelompok ataupun mandiri dengan catatan tidak menyimpang dari tugas yang diberikan guru.

2) Perancangan Langkah-langkah Penyelesaian Proyek. Pada tahap ini, peserta didik merancang langkah-langkah kegiatan penyelesaian proyek dari awal sampai akhir beserta pengelolaannya. Kegiatan perancangan proyek ini berisi aturan main dalam pelaksanaan tugas proyek, pemilihan aktivitas yang dapat mendukung tugas proyek, pengintegrasian berbagai kemungkinan penyelesaian tugas proyek, perencanaan sumber/bahan/alat yang dapat mendukung penyelesaian tugas projek, dan kerja sama antaranggota kelompok. 
3) Penyusunan Jadwal Pelaksanaan Proyek. Pada tahap ini, peserta didik di bawah pendampingan guru melakukan penjadwalan semua kegiatan yang telah dirancangnya. Jadwal tersebut menunjukkan berapa lama proyek itu harus diselesaikan tahap demi tahap.

4) Penyelesaian Proyek dengan Fasilitasi dan Monitoring Guru. Langkah ini merupakan langkah pengimplementasian rancangan proyek yang telah dibuat. Aktivitas yang dapat dilakukan dalam kegiatan proyek di antaranya adalah dengan a) membaca, b) meneliti, c) observasi, d) interviu, e) merekam, f) berkarya seni, g) mengunjungi objek projek, atau h) akses internet. Guru bertanggung jawab memonitor aktivitas peserta didik dalam melakukan tugas proyek mulai proses hingga penyelesaian proyek. Pada kegiatan monitoring, guru membuat rubrik yang akan dapat merekam aktivitas peserta didik dalam menyelesaikan tugas proyek.

5) Penyusunan Laporan dan Presentasi/Publikasi Hasil Proyek. Hasil proyek dalam bentuk produk, baik itu berupa produk karya tulis, karya seni, atau karya teknologi/prakarya dipresentasikan dan/atau dipublikasikan kepada peserta didik yang lain dan guru atau masyarakat dalam bentuk pameran produk pembelajaran.

6) Evaluasi Proses dan Hasil Proyek. Guru dan peserta didik pada akhir proses pembelajaran melakukan refleksi terhadap aktivitas dan hasil tugas proyek. Proses refleksi pada tugas proyek dapat dilakukan secara individu maupun kelompok. Pada tahap evaluasi, peserta didik diberi kesempatan mengemuka-kan pengalamannya selama menyelesaikan tugas proyek yang berkembang dengan diskusi untuk memperbaiki kinerja selama menyelesaikan tugas proyek. Pada tahap ini pun dilakukan umpan balik terhadap proses dan produk yang telah dilakukan.

Melalui tulisan ini dideskripsikan hasil best practices berupa proses dan hasil pembelajaran cerpen (mengidentifikasi nilai- nilai pada cerpen) dengan menggunakan model pembelajaran Project Based Learning (PjBL) berbantuan materi ajar local/kontekstual. Dalam hal ini digunakan cerpen berjudul Awik-awik karya Ayu Nurmalayani (penulis sendiri) yang berisi kondisi sosial budaya remaja Sasak.

\section{METODE}

Jenis penelitian ini adalah penelitian kualitatif berupa penelitian survei. Dalam hal ini, diamati dan dianalisis gambaran kemampuan siswa kelas XI SMA Negeri 1 Labuapi dalam hal menemukan nilai-nilai kehidupan dalam cerpen. Penelitian ini dilakukan melalui tiga tahapan strategis, yaitu prapenelitian, pelaksanaan penelitian, dan pascapenelitian (Mahsun, 2010). Populasi penelitian ini adalah semua siswa kelas XI SMA Negeri 1 Labuapi, Kabupaten Lombok Barat (kelas XI IPA-1, XI IPA-2, dan XI IPS). Sementara itu, sampel penelitian ini ditetapkan melalui teknik purposive sampling, yakni penentuan sampel yang disesuaikan dengan tujuan penelitian (Arikunto, 2006). Dalam hal ini, sampelnya adalah siswa kelas XI IPA 1. Kelas XI IPA 1 dipilih karena paling heterogen dan dianggap mampu mewakili kelas-kelas yang lain. Sesuai dengan jenis data yang akan dikumpulkan, metode yang digunakan dalam proses pengumpulan data dalam penelitian ini adalah metode observasi dan telaah dokumen. Metode observasi digunakan untuk mengambil data terkait gambaran proses pembelajaran, sedangkan metode telaah dokumen digunakan untuk mengambil data terkait gambaran kemampuan siswa dalam menemukan nilai-nilai kehidupan dalam cerpen. Dokumen yang ditelaah adalah hasil belajar siswa. Analisis data dilakukan dengan mengikuti prinsip-prinsip dalam penelitian kualitatif, yaitu tahap reduksi data, penyajian atau organisasi data, dan verifikasi atau interpretasi data (Miles dan Huberman, 1992:16-20).

\section{HASIL DAN PEMBAHASAN Proses Pembelajaran}

Proses pembelajaran yang dimaksud adalah gambaran keaktifan siswa dan 
gambaran perilaku sosial atau karakter siswa selama mengikuti proses pembelajaran. Hasil berupa keaktifan dan perilaku siswa ini diperoleh melalui obeservasi selama kegiatan berlangsung. Secara umum hampir semua tahapan kegiatan pembelajaran dilaksanakan atau direspon oleh sebagian besar atau semua siswa dan hanya beberapa kegiatan saja yang direspon oleh beberapa siswa. Gambaran keaktifan siswa selama pembelajaran dapat dilihat pada tabel 1 .

\section{Tabel 1. Gambaran Keaktifan Siswa} Selama Pembelajaran

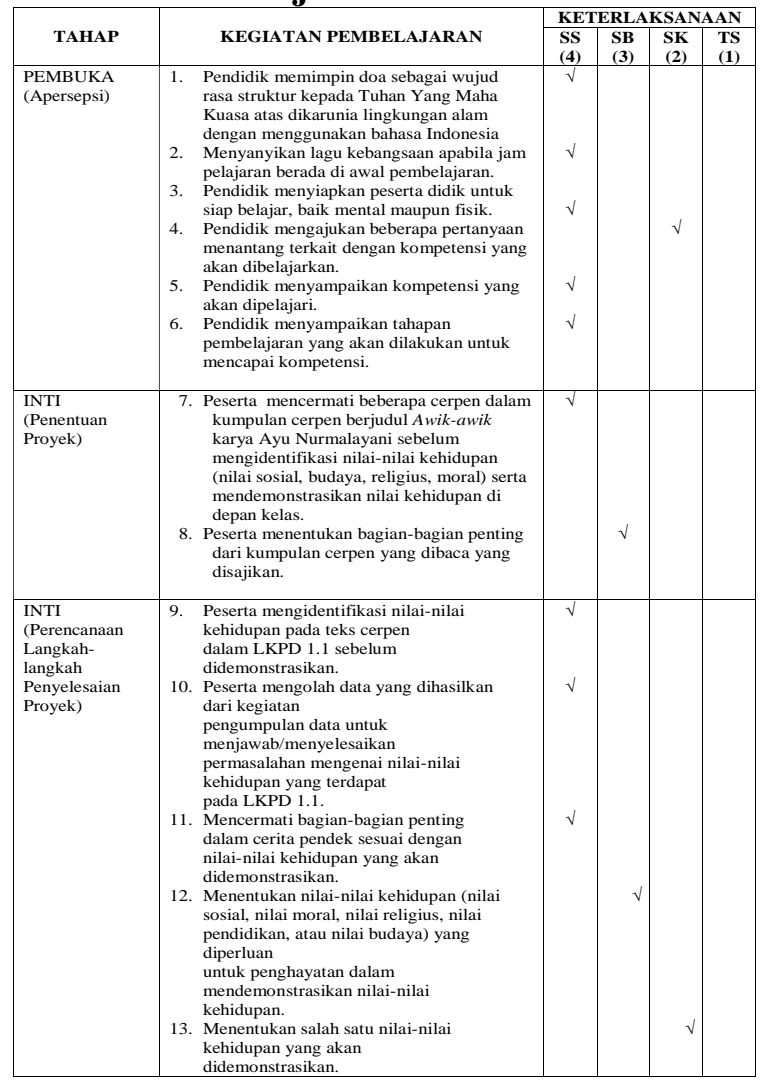

Berdasarkan data pada tabel 1, dapat dijelaskan bahwa dari 17 aktivitas pembelajaran, 11 aktivitas pembelajaran dilaksanakan atau direspon oleh semua siswa, 3 aktivitas pembelajaran dilaksanakan atau direspon oleh sebagian besar siswa, dan 3 kegiatan lainnya dilaksanakan atau direspon oleh sebagian kecil siswa. Artinya, keaktifan siswa sangat tinggi karena sebagian besar kegiatan pembelajaran direspon oleh semua atau sebagian besar siswa.

Adapun gambaran sikap atau perilaku (karakter) siswa selama mengikuti pembelajaran dapat dicermati pada tabel 2 .

\section{Tabel 2. Gambaran Perilaku atau Karakter Siswa}

\begin{tabular}{|l|l|c|c|c|c|}
\hline \multirow{2}{*}{ No } & \multicolumn{1}{|c|}{ Nama } & \multicolumn{4}{|c|}{ Aspek Penilaian* } \\
\cline { 3 - 6 } & & Jujur & Disiplin & $\begin{array}{c}\text { Tanggung } \\
\text { Jawab }\end{array}$ & Sosialis \\
\hline 1. & Siswa ke-1 & 4 & 3 & 4 & 3 \\
\hline 2. & Siswa ke-2 & 4 & 2 & 4 & 4 \\
\hline 3. & Siswa ke-3 & 4 & 4 & 4 & 4 \\
\hline 4. & Siswa ke-4 & 4 & 4 & 4 & 4 \\
\hline 5. & Siswa ke-5 & 4 & 3 & 2 & 3 \\
\hline 6. & Siswa ke-6 & 4 & 4 & 4 & 3 \\
\hline 7. & Siswa ke-7 & 4 & 4 & 3 & 3 \\
\hline 8. & Siswa ke-8 & 4 & 4 & 4 & 2 \\
\hline 9. & Siswa ke-9 & 3 & 2 & 4 & 4 \\
\hline 10. & Siswa ke-10 & 4 & 3 & 4 & 4 \\
\hline 11. & Siswa ke-11 & 3 & 2 & 4 & 3 \\
\hline 12. & Siswa ke-12 & 4 & 4 & 4 & 4 \\
\hline 13. & Siswa ke-13 & 4 & 3 & 4 & 4 \\
\hline 14. & Siswa ke-14 & 4 & 4 & 4 & 4 \\
\hline 15. & Siswa ke-15 & 4 & 3 & 2 & 3 \\
\hline 16. & Siswa ke-16 & 4 & 2 & 4 & 3 \\
\hline 17. & Siswa ke-17 & 4 & 4 & 3 & 2 \\
\hline 18. & Siswa ke-18 & 4 & 4 & 4 & 4 \\
\hline 19. & Siswa ke-19 & 4 & 3 & 4 & 3 \\
\hline 20. & Siswa ke-20 & 4 & 4 & 4 & 4 \\
\hline 21. & Siswa ke-21 & 4 & 4 & 4 & 4 \\
\hline 22. & Siswa ke-22 & 4 & 4 & 4 & 3 \\
\hline 23. & Siswa ke-23 & 3 & 2 & 4 & 4 \\
\hline & \% Sangat Baik (4) & $87 \%(20)$ & $57 \%(13)$ & $83 \%(19)$ & $52 \%(12)$ \\
\hline & \% Baik (3) & $13 \%(3)$ & $26 \%(6)$ & $8.5 \%(2)$ & $39 \%(9)$ \\
\hline & \% Cukup Baik (CB) & & $17 \%(4)$ & $8.5 \%(2)$ & $8.5 \%(2)$ \\
\hline & \% Tidak Baik (1) & & & & \\
\hline & & & & & \\
\hline
\end{tabular}

Ket: Sangat Baik (4), Baik (3), Cukup Baik (2), dan Tidak Baik (1)

Berdasarkan tabel 2, hampir semua siswa memiliki perilaku yang sangat baik dan baik. Bahkan tidak dijumpai siswa yang memiliki perilaku tidak baik dan hanya beberapa saja yang berperilaku cukup baik. Untuk sikap jujur, 87\% siswa (20 orang) sangat baik dan $13 \%$ (3 orang) baik. Untuk kedisiplinan 57\% (13 orang) sangat baik, 26\% (6 orang) baik, dan 17\% (4 orang) cukup baik. Untuk sikap tanggung jawab 83\% (19 orang) sangat baik, $8.5 \%$ (2 orang) baik, dan $8.5 \%$ (2 orang) cukup baik. Sementara itu, untuk sikap sosialis 52\% (12 orang) sangat baik, 39\% (9 orang) baik, dan $8.5 \%$ (2 orang) cukup baik.

\section{Hasil Pembelajaran}

Hasil pembelajaran yang dimaksud adalah gambaran hasil belajar siswa, yakni kemampuan siswa dalam menemukan nilainilai kehidupan pada cerpen. Gambaran hasil belajar siswa dimaksud dapat dilihat pada tabel 3 . 
Tabel 3. Kemampuan Menemukan Nilainilai Kehidupan pada Cerpen

\begin{tabular}{|c|c|c|c|c|c|c|c|c|c|}
\hline \multirow[b]{2}{*}{ No } & \multirow[b]{2}{*}{ Nama Siswa } & \multicolumn{5}{|c|}{ Butir Soal* } & \multirow[b]{2}{*}{ Jlh } & \multirow[b]{2}{*}{$\mathrm{N}$} & \multirow[b]{2}{*}{ Ket. } \\
\hline & & $\mathbf{A}$ & B & $\mathrm{C}$ & D & $\mathbf{E}$ & & & \\
\hline 1. & Siswa ke-1 & 4 & 3 & 3 & 2 & 2 & 14 & 70 & BT \\
\hline 2. & Siswa ke-2 & 4 & 2 & 3 & 3 & 2 & 14 & 70 & BT \\
\hline 3. & Siswa ke-3 & 4 & 4 & 3 & 3 & 3 & 17 & 85 & $\mathrm{~T}$ \\
\hline 4. & Siswa ke-4 & 4 & 4 & 4 & 3 & 2 & 17 & 85 & $\mathrm{~T}$ \\
\hline 5. & Siswa ke-5 & 4 & 3 & 3 & 3 & 2 & 15 & 75 & $\mathrm{~T}$ \\
\hline 6. & Siswa ke-6 & 4 & 4 & 3 & 3 & 3 & 17 & 85 & $\mathrm{~T}$ \\
\hline 7. & Siswa ke-7 & 4 & 4 & 3 & 3 & 3 & 17 & 85 & $\mathrm{~T}$ \\
\hline 8. & Siswa ke-8 & 4 & 4 & 3 & 3 & 2 & 16 & 80 & $\mathrm{~T}$ \\
\hline 9. & Siswa ke-9 & 3 & 3 & 2 & 3 & 3 & 14 & 70 & BT \\
\hline 10. & Siswa ke-10 & 4 & 3 & 3 & 3 & 2 & 15 & 75 & $\mathrm{~T}$ \\
\hline 11. & Siswa ke-11 & 3 & 3 & 2 & 2 & 3 & 13 & 65 & BT \\
\hline$\frac{11 .}{12 .}$ & Siswa ke-12 & 4 & 4 & 2 & 3 & 3 & 16 & 80 & $\mathrm{~T}$ \\
\hline 13. & Siswa ke-13 & 4 & 3 & 3 & 3 & 3 & 16 & 80 & $\mathrm{~T}$ \\
\hline 14. & Siswa ke-14 & 4 & 4 & 3 & 3 & 3 & 17 & 85 & $\mathrm{~T}$ \\
\hline 15. & Siswa ke-15 & 4 & 4 & 3 & 4 & 2 & 17 & 85 & $\mathrm{~T}$ \\
\hline 16. & Siswa ke-16 & 4 & 3 & 3 & 3 & 3 & 16 & 80 & $\mathrm{~T}$ \\
\hline 17. & Siswa ke-17 & 4 & 4 & 4 & 4 & 3 & 19 & 95 & $\mathrm{~T}$ \\
\hline 18. & Siswa ke-18 & 4 & 3 & 3 & 3 & 2 & 14 & 75 & $\mathrm{~T}$ \\
\hline 19. & Siswa ke-19 & 3 & 3 & 4 & 3 & 3 & 16 & 80 & $\mathrm{~T}$ \\
\hline 20. & Siswa ke-20 & 4 & 4 & 2 & 3 & 3 & 16 & 80 & $\mathrm{~T}$ \\
\hline 21. & Siswa ke-21 & 4 & 3 & 3 & 3 & 3 & 16 & 80 & $\mathrm{~T}$ \\
\hline$\frac{21 .}{22 .}$ & Siswa ke-22 & 4 & 4 & 3 & 3 & 3 & 17 & 85 & $\mathrm{~T}$ \\
\hline 23. & Siswa ke-23 & 3 & 4 & 3 & 3 & 2 & 14 & 75 & $\mathrm{~T}$ \\
\hline \multicolumn{2}{|c|}{ Jumlah } & 88 & 80 & 68 & 69 & 60 & 365 & 1825 & 19 \\
\hline \multicolumn{2}{|c|}{ Rerata } & 3.83 & 3.48 & 2.96 & 3.00 & 2.61 & & 79.35 & \\
\hline \multicolumn{2}{|c|}{ \% Ketuntasan } & & & & & & & & $83 \%$ \\
\hline
\end{tabular}

Berdasarkan tabel 3, dapat dikemukakan bahwa jumlah siswa yang tuntas (mencapai KKM 75) adalah sebanyak 19 orang atau $83 \%$. Artinya ketuntasan kelasikal setelah dimaksimalkan tindakan pembelajaran dengan menggunakan model pembleejran PjBL dengan bantuan cerpen lokal/kontekstual ketuntasan klasikal siswa XI-1 SMAN 1 Labuapi adalah 83\%.

Gambaran aktivitas dan hasil pembelajaran menggunakan rubrik seperti disarankan Nurgiantoro (2011) sebagaimana telah digambarkan di atas menunjukkan bahwa terjadi peningkatan jumlah siswa yang terlibat pada semua tahapan pembelajaran. Keaktifan siswa terus meningkat. Guru berhasil memfasilitasi keterlibatan siswa. Hal ini sejalan dengan pendapat Trianto (2017:18) yang mengatakan bahwa dalam pembelajaran, guru mesti bertindak sebagai model, fasilitator, pembelajar, dinamisator, pengamat, dan peneliti dalam mengarahkan kegiatan belajar siswa. Guru juga telah menunjukkan dirinya sebagai model, juga memberikan contoh-contoh yang dapat ditiru siswa. Berkaitan dengan hal ini, Parson (dalam Trianto, 2017) menyatakan bahwa guru penting untuk memodelkan sesuatu secara eksplisit sehingga siswa dapat mengobservasi model dan melakukan peniruan secara baik. Intensitas keterlibatan siswa yang terus meningkat, menunjukkan bahwa siswa berhasil menghubungkan pemahamannya dengan model yang diberikan guru. Melalui kegiatan menganalisis model, guru membimbing siswa melakukan pengaitan untuk melakukan peniruan dari contoh-contoh (Trianto, 2017:32).

Dalam konteks paparan di atas, guru telah berhasil memotivasi siswa sehingga terlibat secara aktif dalam pembelajaran. Hal ini tidak lepas dari upaya yang dilakukan guru, yang memberi penguatan kepada siswa pada setiap tahapan kegiatan yang dilakukan. Hal ini sejalan dengan pendapat Dimyati dan Mujiono (2012:139) yang menyatakan bahwa motivasi sangat berpengaruh terhadap kegiatan belajar dan mutu hasil belajar. Usman (2001) juga mengatakan bahwa salah satu tujuan pemberian penguatan adalah untuk meningkatkan kualitas kegiatan belajar dan membina tingkah laku siswa yang produktif. Penguatan juga merupakan hal yang harus diupayakan secara berkelanjutan pada setiap kegiatan siswa.

Dampak pemberian motivasi dan penguatan tidak hanya terjadi pada proses pembelajaran, tetapi juga hasil belajar siswa. Dalam konteks hasil belajar juga telah tergambar dampak motivasi yang diberika guru. Tercatat ketuntasan klasikanya adalah 83\%. Meskipun demikian, hasil ini lebih rendah dari pencapaian siswa yang sama untuk kompetensi berbicara. Untuk kompetensi berbicara, rerata kualitas penampilan berbicara siswa secara klasikal adalah 85.4 (kategori sangat baik) dengan ketuntasan klasikal 90\% (Intiana, dkk. 2017).

\section{SIMPULAN}

Berdasarkan gambaran hasil yang telah dipaparkan di atas, beberapa hal patut dikemukakan sebagai simpulan, yakni sebagai berikut.

1. Keaktifan siswa dalam pembelajaran sangat tinggi karena sebagian besar kegiatan pembelajaran direspon oleh semua atau sebagian besar siswa.

2. Hampir semua siswa memiliki perilaku yang sangat baik dan baik. Bahkan tidak dijumpai siswa yang memiliki perilaku tidak baik dan hanya beberapa saja yang berperilaku cukup baik. Untuk sikap jujur, $87 \%$ siswa (20 orang) sangat baik dan 
13\% (3 orang) baik. Untuk kedisiplinan $57 \%$ (13 orang) sangat baik, 26\% (6 orang) baik, dan $17 \%$ (4 orang) cukup baik. Untuk sikap tanggung jawab 83\% (19 orang) sangat baik, $8.5 \%$ (2 orang) baik, dan $8.5 \%$ (2 orang) cukup baik. Sementara itu, untuk sikap sosialis 52\% (12 orang) sangat baik, 39\% (9 orang) baik, dan $8.5 \%$ (2 orang) cukup baik.

3. Pembelajaran cerpen dengan menggunakan model pembelajaran Project Based Learning (PjBL) berbantuan materi ajar lokal/kontekstual, dapat meningkatkan kemampuan siswa dalam mengidentifikasi nilai-nilai kehidupan dalam cerpen, yakni sampai mencapai $83 \% \quad(19$ dari 23 siswa tuntas/mencapai KKM).

\section{SARAN}

Beberapa hal yang dapat direkomendasikan sebagai saran dari hasil kegiatan ini adalah sebagai berikut. Pertama, para guru disarankan menggunakan model pembelajaran Project Based Learning (PjBL) karena dapat meningkatkan keaktifan siswa. Kedua, para guru disarankan menggunakan materi yang kontekstual atau dekat dengan kehidupan keseharian siswa karena akan lebih cepat dipahami.

\section{UCAPAN TERIMAKASIH}

Ucapan terimakasih terutama disampaikan kepada Kepala Sekolah SMAN 1 Labuapi yang telah memotivasi penulis untuk melakukan kegiatan ini. Ucapan yang sama juga disampaikan kolega guru di SMAN 1 Labuapi yang telah mendukung penyelesaian tulisan ini. Terimakasih juga disampaikan kepada Jurnal Ilmiah Mandala Education, http://ejournal.mandalanursa.org/index.php/J IME/index, yang telah memuat tulisan ini.

\section{DAFTAR PUSTAKA}

Aminuddin. (1999). Pembelajaran Terpadu Bahasa dan Sastra Indonesia. Malang: FPBS IKIP Malang

Abidin, Y. (2014). Desain Sistem Pembelajaran dalam Konteks Kurikulum 2013. Bandung: Refika Aditama.
Dimyati dan Mudjiono, (2012). Belajar dan Pembelajaran. Jakarta: Rineka Cipta

Daryanto. (2014). Pendekatan Pembelajaran Saintifik Kurikulum 2013. Yogyakarta: Gava Media.

Intiana, S.R.H., dkk (2017). Peingkatan Keterampilan Berbahasa Indonesia dengan Metode Pemodelan Berpola Lesson Study pada Siswa Kelas XI SMA Negeri 1 Labuapi. Laporan Penelitian tidak diterbitkan. Universitas Mataram

Kosasih, E. (2014). Strategi Belajar dan Pembelajaran Implementasi Kurikulum 2013. Bandung: Yrama Widya.

Keser, H. \& Karahoca, D. 2010. Designing a project manajement e-course by using project base learning. Procedia Social and Behavioral Sciences 2 (2010) 5744-5754.

Musaddat, S., dkk. (2016). Pemetaan Kualitas Alumni Program Studi Pendidikan Bahasa, Sastra Indonesia, dan Daerah (PBSID) FKIP Universitas Mataram dalam Hal Perencanaan dan Pelaksanaan Pembelajaran. Laporan Penelitian tidak diterbitkan. Universitas Mataram

Nurgiantoro, B. (2011). Penilaian dalam Pengajaran Bahasa dan Sastra. Yogyakarta: BPFE

Nurhadi. (2012). Pendekatan Kontekstual. Malang: UM Press

Sukardi. (2015). Strategi Pembelajaran: PAIKEM dan Pembelajaran Berbasis Saintifik. Panduan PLPG tidak diterbitkan. Universitas Mataram

Sutirman. (2013). Media dan Model-Model Pembelajaran Inovatif. Yogyakarta: Graha Ilmu.

Soeharto, K., Suprajitno, Sudjimat, dan Sulton. (2003). Teknologi Pembelajaran: Pendekatan Sistem, Konsepsi dan Model, SAP, Evaluasi, Sumber Belajar dan Media. Surabaya: SIC Stuffebeam. L. \&. Shinkfield. J. 1985. Systematic Evaluation. Boston. Kluwer Nijhoff Publishing 
Trianto. (2017). Model Pembelajaran Terpadu dalam Teori dan Praktek. Jakarta: Prestasi Pustaka

Usman, M. Uzer. (2001). Menjadi Guru Profesional. Bandung: Remaja Rosdakarya 